\title{
Biological Characteristics and Molecular Mechanism of Fludioxonil Resistance in Botrytis cinerea From Henan Province of China
}

\author{
Feng Zhou, ${ }^{1,2}$ Hai-Yan Hu, ${ }^{1}$ Yu-Lu Song, ${ }^{2}$ Yu-Qing Gao, ${ }^{2}$ Qi-Li Liu, ${ }^{1,2}$ Pu-Wen Song, ${ }^{1}$ Er-Yong Chen, ${ }^{1}$ Yong-Ang Yu, ${ }^{1}$ Dong-Xiao Li, \\ and Cheng-Wei $\mathrm{Li}^{1, \dagger}$ \\ ${ }^{1}$ Henan Engineering Research Center of Crop Genome Editing, Henan Institute of Science and Technology, Xinxiang 453003, \\ China \\ ${ }^{2}$ College of Resources \& Environmental Science, Henan Institute of Science and Technology, Xinxiang 453003, China
}

\begin{abstract}
The gray mold caused by Botrytis cinerea has a significant impact on tomato production throughout the world. Although the synthetic fungicide fludioxonil can effectively control $\mathrm{B}$. cinerea, there have been several reports of resistance to this fungicide. This study indicated that all of the fludioxonil-resistant strains tested, including one field-resistant isolate and four laboratory strains, had reduced fitness relative to sensitive isolates. In addition to having reduced growth, sporulation, and pathogenicity, the resistant strains were more sensitive to osmotic stress and had significantly $(P<0.05)$ higher peroxidase activity. BOs1, a kinase in the high-osmolarity glycerol stress response signal transduction pathway, is believed to harbor mutations related to fludioxonil resistance. Sequence analysis of their BOs 1 sequences indicated that the fludioxonil-resistant field isolate, XXtom1806,

chemotaxis receptors, and phosphatases domain, which associated with fludioxonil binding. Similarly, two of the laboratory strains, XXtom-Lab1 and XXtom-Lab4, had three (Q846S, I1126S, and G415D) and two (P1051S and V1241M) point mutations, respectively. A third strain, XXtom-lab3, had a 52-bp insertion that included a stop codon at amino acid 256. Interestingly, the BOs1 sequence of the fourth laboratory strain, XXtom-lab5, was identical to those of the sensitive isolates, indicating that an alternative resistance mechanism exists. The study also found evidence of positive cross-resistance between fludioxonil and the dicarboximide fungicides procymidone and iprodione, but no cross-resistance was detected with any other fungicides tested, including boscalid, carbendazim, tebuconazole, and fluazinam.
\end{abstract} had four point mutations resulting in four amino acid changes (I365S, S531G, T565N, and T1267A) and three amino acids (I365S, S531G, and $\mathrm{T} 565 \mathrm{~N})$ in the histidine kinases, adenylyl cyclases, methyl-accepting
Keywords: Botrytis cinerea, biological characteristics, cross-resistance, fludioxonil, resistance mechanism
Botrytis cinerea Pers (teleomorph Botryotinia fuckeliana Whetzel) is a ubiquitous necrotrophic plant pathogen belonging to the Ascomycota (van Kan et al. 2017). It infects $>1,400$ crop species and predominantly affects dicotyledonous species, especially those that bear soft fruits, such as tomatoes and strawberries (Elad et al. 2007; Staats et al. 2005; van Kan 2006; van Kan et al. 2017; Williamson et al. 2007). Disease management in greenhouse crops is highly dependent on the application of fungicides, which are crucial to ensure sustainable production of tomatoes. Commonly used fungicide groups include the benzimidazoles, dicarboximides, carbamates, quinone outside inhibitors, sterol biosynthesis inhibitors, anilinopyrimidines, succinate dehydrogenase inhibitors, and phenylpyrroles (Amiri et al. 2013; Rosslenbroich and Stuebler 2000; Zhang and Ma 2014; Zhou et al. 2017). However, owing to its short lifecycle, high genetic variability, and abundant reproductive capacity, $B$. cinerea is well known as a high-risk pathogen for the development of fungicide resistance (Leroux et al. 2002; Sang et al. 2018). Indeed, there have been many reports of highly resistant isolates of $B$. cinerea in China arising from excessive or inappropriate uses of fungicides, which have jeopardized the effectiveness of a broad range of fungicides,

\section{${ }^{\dagger}$ Corresponding author: C.-W. Li; lichengweiwau@ hotmail.com \\ F. Zhou and H.-Y. Hu contributed equally to this work.}

Funding: This study was sponsored by The Key Scientific and Technological Research Projects in Henan Province grant 192102110056, Foundation for High-level Talents in Henan Institute of Science and Technology (HIST) grant 2018022, and Training Program of Innovation and Entrepreneurship for Undergraduates in HIST grant 2019CX044.

The author(s) declare no conflict of interest.

Accepted for publication 21 October 2019.

(C) 2020 The American Phytopathological Society including carbendazim, iprodione, procymidone, diethofencarb, pyrimethanil, cyprodinil, and fenhexamid (Hu et al. 2011; Liu et al. 2003; Zhang et al. 2003, 2013; Zhou et al. 2017).

Fludioxonil is a member of the phenylpyrrole fungicides. Although the mode of action has not been fully revealed, it is believed that fludioxonil is involved in the high-osmolarity glycerol (HOG) stress response signal transduction pathway (Qiu et al. 2018). Phenylpyrroles exhibit broad-spectrum activity against a variety of fungal pathogens and have been used in $>900$ agricultural products (Brandhorst and Klein 2019; Yoshimi et al. 2005). Although fludioxonil has been widely used for the control of numerous plant pathogens over the past 30 years, it was only registered in China for the control of gray mold in 2018 (Sang et al. 2018). The reports of fludioxonilresistant $B$. cinerea isolates are, therefore, of great concern (Amiri and Peres 2014; Amiri et al. 2013, 2014; Sang et al. 2018). Some previous studies have shown that fludioxonil-resistant isolates have reduced fitness associated with an increased sensitivity to high osmotic stress, which is consistent with the biochemical mechanism of fludioxonil that is known to inhibit the HOG cascade of mitogenactivated protein kinase (MAPK) signaling pathway (Lew 2010; Sang et al. 2018). Indeed, there have been several reports of specific amino acid mutations and genetic polymorphism in the MAPK BOs 1 (BC1G_00374) of $B$. cinerea that linked to fludioxonil resistance (Gong et al. 2018; Sang et al. 2018). For example, mutations have been identified in the ATPase domain of the $\mathrm{C}$ terminus from highresistance laboratory strains of $B$. cinerea, whereas mutations in low-resistance field populations of $B$. cinerea are mainly distributed in the histidine kinases, adenylyl cyclases, methyl-accepting chemotaxis receptors, and phosphatases (HAMP) domain in the $\mathrm{N}$ terminus of osmosensing histidine kinase, which is considered to be the fungicide binding site (Ren et al. 2016; Sang et al. 2018). Similar results have also been found in many other plant pathogenic fungi, where induced amino acid changes in the BOs1 protein as a result of ultraviolet treatment or repeated exposure to fludioxonil have been associated with high levels of resistance (Avenot and Michailides 2015; Dry et al. 2004; Duan et al. 2014; Han et al. 2017; Jung et al. 2012; 
Li and Xiao 2008; Peters et al. 2008; Ren et al. 2016; Tückmantel et al. 2011; Wu et al. 2015). However, it is interesting to note that only a low level of fludioxonil resistance has been detected in field populations (Avenot and Michailides 2015; Dry et al. 2004; Duan et al. 2014; Han et al. 2017; Jung et al. 2012; Li and Xiao 2008; Peters et al. 2008; Ren et al. 2016; Tückmantel et al. 2011; Wu et al. 2015). There have been insufficient studies to determine whether cross-resistance with other common fungicides can be directly linked to fludioxonil resistance in B. cinerea, although previous reports of fludioxonil resistance have indicated a degree of cross-resistance with a range of fungicides, including tolclofos-methyl, vinclozolin, and iprodione. In addition, fludioxonil resistance has been found to result in increased sensitivity to some antifungal compounds, such as pyraclostrobin (Malandrakis et al. 2013).

These results indicate that further investigation of the biological characteristics and molecular mechanism of fludioxonil-resistant isolates is needed to fully understand the mechanisms of resistance in different populations. The specific objectives of this study were, therefore, to (1) compare the fitness and physiological characteristics of different fludioxonil-resistant and -sensitive isolates, (2) assess the potential for cross-resistance between fludioxonil and other widely used fungicides, and (3) investigate molecular mechanisms of fludioxonil resistance.

\section{Materials and Methods}

Isolates of $\boldsymbol{B}$. cinerea, media, and culture conditions. The pathogen isolates used in this study were collected from infected greenhouse tomatoes in Xinxiang city, Henan Province of China in 2018. Eight isolates were collected from infected tomato leaves from different greenhouses. All of the $B$. cinerea isolates were first purified by single-spore isolation and thereafter, maintained on potato dextrose agar (PDA; $200 \mathrm{~g} /$ liter of potato, $20 \mathrm{~g} /$ liter of agar, and 20 $\mathrm{g} /$ liter of dextrose). After approximately 6 days of dark incubation at $22^{\circ} \mathrm{C}$, conidial suspensions were prepared in $20 \%$ sterile glycerol and stored at $-20^{\circ} \mathrm{C}$ until use (Zhou et al. 2017). Four laboratory fludioxonil-resistant strains (XXtom-Lab1, XXtom-Lab3, XXtom-Lab4, and XXtom-Lab5 laboratory induced from their parental isolates XXtom1801, XXtom1803, XXtom1804, and XXtom1805, respectively, by fludioxonil taming) were evaluated. The mycelia were used to determine intracellular glycerol accumulation and enzyme activity. For genomic DNA, extractions were prepared by inoculating $200 \mathrm{ml}$ of potato dextrose broth (PDB), which was dark incubated at $22^{\circ} \mathrm{C}$ for $72 \mathrm{~h}$ with shaking (130 $\mathrm{rpm})$, before the samples were prepared in the absence or presence of $0.1 \mu \mathrm{M}$ fludioxonil. After a further $5 \mathrm{~h}$ of incubation, the mycelium was collected and flash frozen in liquid nitrogen according to the protocol of a previous study (Qiu and Shi 2014; Qiu et al. 2018).

Fungicides. Technical-grade concentrates of the fungicides listed in Table 1 were dissolved in either acetone to produce $10-\mathrm{mg} / \mathrm{ml}$ stock solutions or in the case of carbendazim, $0.1 \mathrm{~mol} / \mathrm{liter}$ of hydrochloric acid. The stock solutions were stored at $4^{\circ} \mathrm{C}$. Preliminary tests confirmed that neither of the solvents used had a significant effect on the mycelial growth of $B$. cinerea at the concentrations that were used in this study (data not shown).

Identification of fludioxonil-resistant strains of $\boldsymbol{B}$. cinerea. A protocol used in previous studies was modified to identify fludioxonil-resistant isolates of B. cinerea (Ma et al. 2009; Zhou et al. 2014). Fungal cultures were first established on PDA and incubated for $48 \mathrm{~h}$ at $22^{\circ} \mathrm{C}$ in a growth chamber with a 12-h photoperiod. Mycelial plugs ( $5 \mathrm{~mm}$ in diameter) were then excised from the colony margins and inverted on fresh PDA containing $5 \mu \mathrm{g} / \mathrm{ml}$ of fludioxonil (discriminatory dose). Negative controls were prepared using identical plates that contained no fludioxonil. The mycelial growth of the resulting colonies was assessed after $48 \mathrm{~h}$ of incubation at $22^{\circ} \mathrm{C}$ by measuring their diameters in two perpendicular directions. Isolates capable of growing on PDA media containing $5 \mu \mathrm{g} / \mathrm{ml}$ of fludioxonil were tentatively considered fludioxonil resistant, whereas those unable to grow were designated fludioxonil sensitive (Ma et al. 2009; Zhou et al. 2014). The resistant isolates identified in the first round of screening were then assessed further to determine their $50 \%$ effective concentration $\left(\mathrm{EC}_{50}\right)$ values (effective concentration inhibiting $50 \%$ of colony growth) in accordance with the method used in a previous study (Liang et al. 2015) and fludioxonil at the following concentrations: $0,0.25,0.5,1,2,4,8,16,32,64$, and 128 $\mu \mathrm{g} / \mathrm{ml}$. Each treatment consisted of three replicate plates, and the whole experiment was conducted twice. The $\mathrm{EC}_{50}$ values were determined using linear regression of $\log _{10}$ fungicide concentrations versus the percentage growth inhibition. The resistance factor (RF) of the resistant isolates was then calculated using the following formula:

$\mathrm{RF}=\mathrm{EC}_{50}$ value of resistant isolate/average $\mathrm{EC}_{50}$ value of sensitive isolates tests

Biological characteristics of fludioxonil-resistant strains of B. cinerea. Mycelial growth. The mycelial growth of the fludioxonilresistant $B$. cinerea isolates was assessed using the method of Zhou et al. (2014), with a few modifications. In total, nine isolates were assessed; four fludioxonil-sensitive isolates (XXtom1801, XXtom1802, XXtom1803, and XXtom1804), one fludioxonil-resistant field isolate (XXtom1806), and four fludioxonil-resistant laboratory strains (XXtom-Lab1, XXtom-Lab3, XXtom-Lab4, and XXtom-Lab5) were evaluated. Mycelial plugs $(5 \mathrm{~mm})$ were excised from the edge of 2-day-old colonies and inverted onto fresh PDA plates. The colonies were incubation at $22^{\circ} \mathrm{C}$ with a 12 -h photoperiod, and their diameters were measured at 24,48 , and $72 \mathrm{~h}$ postinoculation. Each isolate was represented by six replicate plates, and the complete experiment was performed twice.

Sporulation. The sporulation of the $B$. cinerea isolates was investigated using a slightly modified version of the Zhou et al. (2017) method. Sensitive and fludioxonil-resistant isolates were first inoculated to the center of fresh PDA plates using mycelial plugs from 72-h-old PDA cultures and dark incubated at $22^{\circ} \mathrm{C}$. After $48 \mathrm{~h}$, the developing cultures were switched to a 14-h dark/10-h light regime for another 10 days of incubation. Each plate was then flooded with $20 \mathrm{ml}$ of distilled water, and the spores were collected by scraping the surface of the plate and aspiration. Spores were harvested and

Table 1. Fungicides used in this study

\begin{tabular}{|c|c|c|c|c|c|}
\hline Common name & Fungicide group & Mode of action & $\begin{array}{l}\text { FRACz } \\
\text { code }\end{array}$ & Source & Solvent \\
\hline Iprodione $(95.3 \%)$ & Dicarboximide & Inhibition of mitochondrial respiration & 2 & Heyi Agrochemical Co. Ltd. & Acetone \\
\hline \multicolumn{6}{|c|}{ Procymidone $(98.0 \%)$} \\
\hline Carbendazim (98.1\%) & $\begin{array}{l}\text { Methyl benzimidazole } \\
\text { carbamate }\end{array}$ & $\begin{array}{l}\text { Inhibition of } \beta \text {-tubulin assembly in } \\
\text { mitosis }\end{array}$ & 1 & Haili Guixi Chemical Co. Ltd. & $\begin{array}{l}0.1 \mathrm{~mol} / \text { liter of } \\
\text { hydrochloric acid }\end{array}$ \\
\hline Fludioxonil (96.0\%) & Phenylpyrrole & Inhibition of mitochondrial respiration & 12 & Hubei Jianyuan Chemical Co. Ltd. & Acetone \\
\hline Tebuconazole (96.2\%) & $\begin{array}{l}14 \alpha \text {-Demethylase } \\
\text { inhibitors }\end{array}$ & $\begin{array}{l}\text { Inhibition of } \mathrm{C} 14 \alpha \text {-demethylase in } \\
\text { sterol biosynthesis }\end{array}$ & 3 & $\begin{array}{l}\text { Sheyang Huanghai Pesticide } \\
\text { Chemical Co. Ltd. }\end{array}$ & Acetone \\
\hline Boscalid $(97.0 \%)$ & Carboxamide & Inhibition of mitochondrial respiration & 7 & $\begin{array}{l}\text { Kangbaotai Fine-Chemical Co. } \\
\text { Ltd. }\end{array}$ & Acetone \\
\hline Fluazinam (95\%) & 2,6-Dinitroanilines & Inhibition of mitochondrial respiration & 29 & $\begin{array}{l}\text { Zhejiang Heben Pesticide \& } \\
\text { Chemicals Co. Ltd. }\end{array}$ & Acetone \\
\hline
\end{tabular}

${ }^{\mathrm{z}}$ FRAC, Fungicide Resistance Action Committee. 
numbered using a hemocytometer (Shanghai Qiujing Biochemical Reagent Instrument Co., Ltd.). Each isolate was represented by three replicated plates, and the whole experiment was performed twice.

Sensitivity to osmotic stress. Plate assays were used to determine the response to osmotic stress using a modified version of a method described in previous studies (Zhou et al. 2014, 2017). Colonies of the sensitive and resistant $B$. cinerea isolates were first established on fresh PDA plates amended with either $\mathrm{NaCl}$ (at $0,1.25,2.5$, 5.0, 10, 20, 40, 80, and $160 \mathrm{~g} /$ liter) or glucose (at 0, 10, 20, 40, $80,100,150,200$, and $400 \mathrm{~g} /$ liter) by inoculation with mycelial plugs from 72-h-old PDA cultures. The percentage radial growth inhibition relative to the negative control, which consisted of identical cultures grown on PDA free of $\mathrm{NaCl}$ and glucose, was calculated from radial growth measurements taken after $48 \mathrm{~h}$ of incubation at $22^{\circ} \mathrm{C}$ with a 12-h photoperiod. Each treatment consisted of six replicate plates, with the whole experiment being performed twice.

Pathogenicity on tomato leaves. A total of nine B. cinerea isolates were assessed: one fludioxonil-resistant field isolate, four fludioxonil-sensitive laboratory strains, and four sensitive isolates. Detached tomato leaves (cultivar Zhongshu number 4) of similar size and growth stage were first excised from tomato plants, rinsed with sterile water, air dried in a transfer hood, and transferred to $15-\mathrm{cm}$ petri dishes lined with wet filter paper to maintain high humidity before being inoculated on their adaxial surfaces with mycelial plugs (6 mm in diameter) cut from the margins of 24-, 48-, and 72-h-old colonies of each $B$. cinerea isolate. The inoculated leaves were incubated in a growth chamber $\left(22^{\circ} \mathrm{C}\right.$; photoperiod of $\left.16 \mathrm{~h}\right)$ for $72 \mathrm{~h}$. The resulting lesions were measured at 24,48 , and $72 \mathrm{~h}$ postinoculation. Each isolate was represented by at least eight leaves, and the entire experiment was performed twice (Zhou et al. 2014, 2017).

Peroxidase extraction and measurement. The peroxidase (POD) extractions and assays ( $\mathrm{Li}$ et al. 2017) were performed using fresh mycelial samples $(0.1 \mathrm{~g})$ that had been ground in liquid nitrogen and suspended in $0.9-\mathrm{ml}$ aliquots of $10 \mathrm{mM}$ phosphate buffer $(\mathrm{pH}$ 7.4). The homogenate was then centrifuged at 2,500 rpm for $10 \mathrm{~min}$ at $4^{\circ} \mathrm{C}$ before the resulting supernatant was collected and assessed for POD activity using a commercial assay kit (Nanjing Jiancheng Bioengineering Institute), and a microplate reader (Varioskan Flash). The POD activity was estimated from the changes in absorbance at $420 \mathrm{~nm}$ resulting from the catalysis of the $\mathrm{H}_{2} \mathrm{O}_{2}$ substrate. One unit was defined as the amount of enzyme that catalyzed $1 \mu \mathrm{g}$ of substrate per $1.0 \mathrm{~g}$ of fresh tissue at $37^{\circ} \mathrm{C}$. The POD activity was calculated using the formula provided by the assay kit manufacturer. Each isolate was represented by three replicate samples, and the entire experiment was performed twice.

Determination of glycerol content. The intracellular glycerol accumulation analysis was conducted using $75 \mathrm{ml}$ of PDB inoculated with a single mycelial plug. The test cultures were dark incubated for 3 days at $22^{\circ} \mathrm{C}$ with shaking at $150 \mathrm{rpm}$ before $0.1 \mu \mathrm{g} / \mathrm{ml}$ of fludioxonil was added to the positive treatments. After another $5 \mathrm{~h}$ of incubation, the mycelium from each culture was collected, ground with a grinder in liquid nitrogen, and transferred to glycerol extraction buffer. The glycerol content was then measured using a commercial glycerol assay kit (Applygen) according to the instructions of the manufacturer. Each isolate was represented by three replicate samples, and the entire experiment was performed twice.

Amplification and sequencing of the $\mathrm{BOs} 1$ gene. Total genomic DNA was extracted from fresh mycelia according to the protocol of a previous study (Milvia et al. 2014) and used as a template for the amplification of the BOs 1 gene using four primer pairs developed in a previous study (Gong et al. 2018), BOs1F1/BOs1R1, BOs1F2/BOs1R2, BOs1F3/BOs1R3, BOs1F4/BOs1R4, and BOs1F5/BOs1R5, which had the following sequences: TACC GATCGAAAAACCCAAC/TGGGCTGGTCTCTCAATCTT, CA ACGTTATGGCACAAAATCTCA/AAGTTTCTGGCCATGGTG TTCA, GGTCGGAACTGATGGAACTC/CGCGGTAAGTGAGG TCTAGG and GCAAACCGTATGATCATGGA/AGCTCGATTC TCCAAAGCAG, TCCCGTTATTCATGTCAGCTT/AAGTACTC GCAGTCGGTGGT, respectively. The PCRs were performed using $50-\mu l$ reaction mixtures containing $25 \mu l$ of $2 \times E S$ Taq Master Mix,
$1.5 \mu \mathrm{l}$ of template DNA, $2 \mu \mathrm{l}$ of each primer, and $21.5 \mu \mathrm{l}$ of $\mathrm{dd}_{2} \mathrm{O}$ (CoWin Biosciences) in a 96-well thermal cycler (Applied Biosystems; Thermo Fisher Scientific) with the following program: an initial denaturation at $94^{\circ} \mathrm{C}$ for 2 min followed by 35 cycles of $94^{\circ} \mathrm{C}$ for $30 \mathrm{~s}, 57^{\circ} \mathrm{C}$ for $30 \mathrm{~s}$, and $72^{\circ} \mathrm{C}$ for $1.5 \mathrm{~min}$ and a final extension at $72^{\circ} \mathrm{C}$ for $10 \mathrm{~min}$. The resulting PCR products were purified, cloned into the pMD19-T vector, and sequenced (Wuhan Genecreate Biotechnology Co. Ltd.). The resulting sequence data were analyzed using the DNAMAN software package (ver.8.0. Lynnon Biosolf; American) to produce multiple sequence alignments that were used to identify amino acid sequence differences between the resistant and sensitive isolates as described in previous studies (Gong et al. 2018; Zhou et al. 2017).

Cross-resistance of fludioxonil-resistant strains to other fungicides. The mycelial growth assay described above was also used to test for cross-resistance between fludioxonil and a range of fungicides, including procymidone, iprodione, boscalid, carbendazim, tebuconazole, and fluazinam. PDA medium was amended with 0 , $0.0625,0.0125,0.025,0.05,0.1,0.2,0.4,0.8$, and $1.6 \mu \mathrm{g} / \mathrm{ml}$ of boscalid, carbendazim, tebuconazole, and fluazinam and amended with $0,1.5625,3.125,6.25,12.5,25,50$, and $100 \mu \mathrm{g} / \mathrm{ml}$ for fludioxonil, procymidone, and iprodione. Each treatment consisted of at least three replicate plates, with the whole experiment being performed twice.

Statistical analysis. Data collected during the study were evaluated by analysis of variance using SPSS software (ver. 17.0; SPSS Inc.), with statistical differences between individual treatments being assessed using Fisher's least significant difference test $(\alpha=0.05$ and $\alpha=0.01$ ). The sequence of the amino acid sequences was analyzed using DNAMAN software (Version 6.0; Lynnon Biosoft)

\section{Results}

Biological characteristics of fludioxonil-resistant $B$. cinerea strains. The mycelial growth of all of the fludioxonil-resistant isolates was significantly reduced relative to the sensitive isolates, particularly for the resistant field isolate XXtom1806 (Table 2). Although the sporulation of the fludioxonil-resistant laboratory strains was similar to the sensitive isolates, the resistant field isolate XXtom 1806 had significantly reduced $(P<0.05)$ sporulation. However, the pathogenicity of all of the fludioxonil-resistant isolates was significantly reduced, with XXtom1806 completely losing pathogenicity on detached leaves of tomato (Table 2). All of the fludioxonilresistant isolates were much more sensitive to osmotic stress than the sensitive ones. The resistant strains exhibited greatly reduced rates even at low concentrations of $\mathrm{NaCl}(2.5$ to $20 \mathrm{~g} /$ liter $)$ and glucose (10 to $100 \mathrm{~g} /$ liter) (Fig. 1).

Glycerol content and POD activity of fludioxonil-resistant B. cinerea strains. The glycerol content of all fludioxonil-resistant strains increased significantly compared with the sensitive isolates when grown in PDB in the absence of fludioxonil (Fig. 2A). However, the addition of $0.1 \mu \mathrm{g} / \mathrm{ml}$ of fludioxonil significantly $(P<$ 0.05) increased glycerol levels of the sensitive isolates XXtom 1801 , XXtom1802, XXtom1803, and XXtom 1804 by 63.13, 32.98, 40.90, and $59.93 \%$, respectively. Although the fludioxonil treatment did significantly $(P<0.01)$ increase the glycerol levels of the resistant strains, the effect was less dramatic, with increases of just $12.63,11.08,20.50,11.92$, and $15.78 \%$ for isolates XXtom 1806 , XXtom-lab1, XXtom-lab3, XXtom-lab4, and XXtom-lab5, respectively (Fig. 2A).

Similar results were also observed with regard to POD activity, with the fludioxonil-resistant isolates having significantly $(P<$ 0.01 ) higher POD activities than the sensitive isolates when grown in PDB in the absence of fludioxonil, and the POD activities of the XXtom1806, XXtom-lab1, XXtom-lab3, XXtom-lab4, and XXtom-lab5 strains increased 6.19-, 6.75-, 3.11-, 1.37-, and 7.15fold, respectively, compared with those of sensitive isolates (average value) (Fig. 2B). However, for the sensitive isolates XXtom1801, XXtom1802, XXtom1803, and XXtom1804, the POD activities increased 4.73-, 9.85-, 9.02-, and 5.32-fold, respectively, compared with those in the absence of fludioxonil, which exhibited a much 
greater increase in POD activity $(P<0.01)$ than those of resistant strains on the addition of $0.1 \mu \mathrm{g} / \mathrm{ml}$ of fludioxonil (Fig. 2B).

Sequence analysis of the $B O s 1$ gene in fludioxonil-resistant strains of $\boldsymbol{B}$. cinerea. The four sensitive isolates had identical BOs1 sequences, whereas four of the resistant strains (XXtom1806, XXtom-lab1, XXtom-lab3, and XXtom-lab4) contained several changes, including point mutations, that have been previously associated with fludioxonil resistance (Table 3). The fludioxonil-resistant field isolate XXtom 1806 had four point mutations corresponding to the following amino acid changes: I365S, S531G, T565N, and T1267A; three of these were located in the six HAMP domains, whereas the fourth, T1267A, was in the $\mathrm{C}$ terminus of the BoS1 protein. In contrast, the laboratory strain XXtom-lab3 had a 52-bp insertion encoding 16 amino acids at amino acid position 240, resulting in a premature stop codon at amino acid position 256, whereas the laboratory strain XXtom-Lab1 had point mutations of Q846S and I1126S, and XXtom-Lab4 had point mutations of G415D, P1051S, and V1241M. The G415D and Q846S changes resided in the six HAMP domains, and the I1126S and V1241M resided in the HATPase_C domain and the $\mathrm{C}$ terminus of BoS1, respectively, whereas P1051S is located between the HATPase_C domain and the Rec domain of BoS1. The BOs1 gene of the laboratory strain, XXtom-lab5, was identical to the sequences of the sensitive isolates, which indicates that the observed resistance in this isolate could result from an alternative resistance mechanism.

Cross-resistance with other fungicides in fludioxonil-resistant strains. There was a positive cross-resistance between fludioxonil, procymidone, and iprodione (Table 4). This is not surprising, because procymidone and iprodione both belong to the dicarboximide group of fungicides, which share the same mode of action targeting the mitogen-activated protein histidine kinase in the HOG1 signal transduction pathway. No cross-resistance was found between fludioxonil and any of the other fungicides tested, including boscalid, carbendazim, tebuconazole, and fluazinam (Table 4).

\section{Discussion}

Fludioxonil is a phenylpyrrole fungicide that exhibits broadspectrum activity against a variety of fungal pathogens (Brandhorst and Klein 2019; Yoshimi et al. 2005). Previous studies have shown that fludioxonil-resistant isolates often exhibit high sensitivity to osmotic stress. The biochemical action mechanism of fludioxonil is known to involve the inhibition of the HOG1 cascade of the MAPK signaling pathway, and previous studies have indicated that alterations to the BOs1 gene in $B$. cinerea are strongly linked to fludioxonil resistance (Lew 2010; Sang et al. 2018). This study evaluated a total of nine $B$. cinerea isolates, including four sensitive isolates, one fludioxonil-resistant field isolate (XXtom1806), and four resistant laboratory strains (XXtom-lab1, XXtom-lab3, XXtom-lab4, and XXtom-lab5). Compared with the sensitive isolates, the fludioxonilresistant isolates exhibited reduced mycelial growth, sporulation, and pathogenicity, suggesting that fludioxonil resistance has a negative effect on fitness, which perhaps explains the relatively low occurrence of resistant isolates in the field (Qiu et al. 2018). Reduced fitness has been reported in several previous studies of fludioxonil resistance in B. cinerea (Gong et al. 2018; Qiu et al. 2018; Ren et al. 2016)

Table 2. Mycelial growth, sporulation, and pathogenicity of sensitive and fludioxonil-resistant strains of Botrytis cinerea

\begin{tabular}{|c|c|c|c|c|c|c|c|c|}
\hline \multirow[b]{2}{*}{ Strains $\left(\mathbf{E C}_{50}\right)^{\mathrm{x}}$} & \multirow[b]{2}{*}{ Phenotype } & \multicolumn{3}{|c|}{ Mycelial growth, $\mathrm{cm} \pm$ standard error $^{\mathrm{y}}$} & \multirow{2}{*}{$\begin{array}{l}\text { Sporulation, spores } \\
\text { per } 1 \mathrm{ml}^{\mathbf{y}}\end{array}$} & \multicolumn{3}{|c|}{ Lesion diameter, $\mathrm{cm}^{\mathrm{y}}$} \\
\hline & & $24 \mathrm{~h}$ & $48 \mathrm{~h}$ & $72 \mathrm{~h}$ & & $24 \mathrm{~h}$ & $48 \mathrm{~h}$ & $72 \mathrm{~h}$ \\
\hline$\overline{\text { XXtom } 180}$ & & $37 \pm 0.0$ & $43 \pm 0.1$ & $77 \pm 0$ & 7.6 & $0.53 \pm 0.03 \mathrm{c} \mathrm{BC}$ & $1.13 \pm 0.12$ de $\mathrm{DE}$ & $2.53 \pm 0$ \\
\hline & & $67 \pm 0.1$ & $3 \mathrm{C}$ & 4 & $\mathrm{C}$ & c C & 1.37 & $\mathrm{BC}$ \\
\hline XXtom1803 (0.030) & & $1.70 \pm 0.06 \mathrm{dD}$ & $3 \pm 0.0$ & & & $0.53 \pm 0.03 \mathrm{c} \mathrm{BC}$ & $1.20 \pm 0.06$ & 2.00 \\
\hline XXtom1804 (0.025) & Sensitive & $1.80 \pm 0.06 \mathrm{dD}$ & $87 \pm 0.09 \mathrm{~d} \mathrm{DE}$ & $5.73 \pm 0.15 \mathrm{dC}$ & $72.67 \pm 34.37 \mathrm{bc} \mathrm{BC}$ & $0.53 \pm 0.03 \mathrm{c} \mathrm{BC}$ & $1.43 \pm 0.12 \mathrm{fE}$ & $2.60 \pm 0.06 \mathrm{dD}$ \\
\hline XXtom1806 (18.06) & Resistant & $0.90 \pm 0.01 \mathrm{aA}$ & $57 \pm 0.09 \mathrm{a} \mathrm{AB}$ & $4.10 \pm 0.15 \mathrm{abA}$ & $9.33 \pm 2.33 \mathrm{a} \mathrm{A}$ & $-{ }^{\mathrm{z}} \mathrm{a} \mathrm{A}$ & $-{ }^{\mathrm{z}}$ a A & $-{ }^{\mathrm{z}}$ a A \\
\hline XXtom-lab1 (>100) & Resistant & $1.07 \pm 0.03 \mathrm{ab} \mathrm{AB}$ & $2.53 \pm 0.12 \mathrm{a} \mathrm{AB}$ & $3.83 \pm 0.09 \mathrm{aA}$ & $494.67 \pm$ & $-{ }^{\mathrm{z}} \mathrm{a} \mathrm{A}$ & $0.77 \pm 0.09 \mathrm{bc} B C$ & $1.17 \pm 0.17 \mathrm{~b} \mathrm{~B}$ \\
\hline XXtom-lab3 (68.46) & Resistant & $1.10 \pm 0.10 \mathrm{ab} \mathrm{ABC}$ & $2.77 \pm 0.17 \mathrm{ab} \mathrm{AB}$ & $4.03 \pm 0.07 \mathrm{abA}$ & $408.67 \pm 11.55$ b B & $-{ }^{\mathrm{z}}$ a A & $0.97 \pm 0.07 \mathrm{~cd} \mathrm{CD}$ & $1.50 \pm 0.15 \mathrm{bc} \mathrm{B}$ \\
\hline XXtom-1 & Resistant & $1.23 \pm 0.03 \mathrm{bc} \mathrm{BC}$ & $2.50 \pm 0.15 \mathrm{a} \mathrm{AB}$ & $3.83 \pm 0.09 \mathrm{aA}$ & $587.33 \pm 29.17 \mathrm{~d} \mathrm{C}$ & $0.50 \pm 0.06 \mathrm{c} \mathrm{BC}$ & $0.63 \pm 0.09 \mathrm{~b} \mathrm{~B}$ & $1.53 \pm 0.23 \mathrm{bc} \mathrm{B}$ \\
\hline XXtom-lab5 (>100) & Resistant & $0.95 \pm 0.09 \mathrm{aAB}$ & $2.40 \pm 0.15 \mathrm{aA}$ & $4.23 \pm 0.18 \mathrm{bA}$ & $522.33 \pm 54.23 \mathrm{~cd} \mathrm{BC}$ & $0.30 \pm 0.15 \mathrm{~b} \mathrm{~B}$ & $0.57 \pm 0.03 \mathrm{~b} \mathrm{~B}$ & $1.43 \pm 0.12$ bc B \\
\hline
\end{tabular}

$\mathrm{x}$ The $50 \%$ effective concentration $\left(\mathrm{EC}_{50}\right)$ values for fludioxonil.

y Different letters in the same column indicate significant differences according to Fisher's least significant difference test $(\alpha=0.05$ and $\alpha=0.01)$.

z No infection.
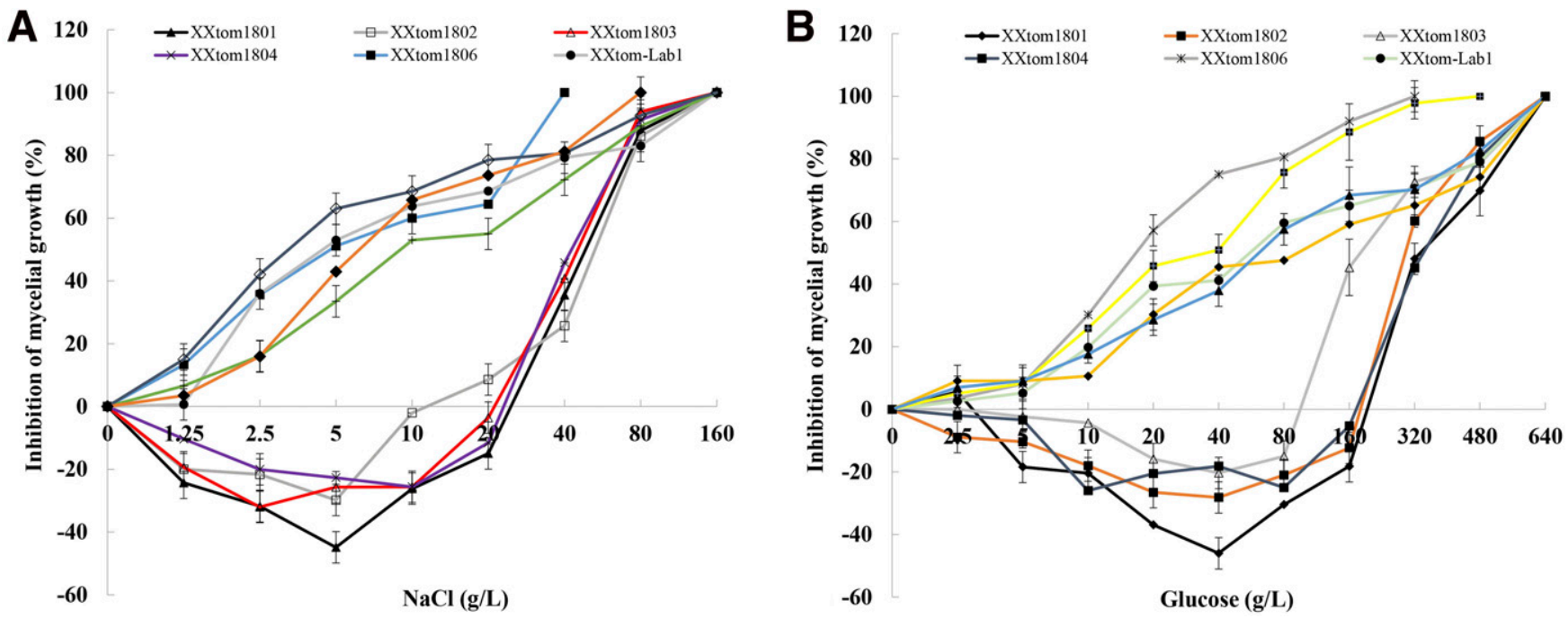

Fig. 1. Osmotic sensitivity of four sensitive and five fludioxonil-resistant strains of Botrytis cinerea to A, NaCl and B, glucose. Isolates XXtom1801, XXtom1802, XXtom1803, and XXtom1804 are sensitive to fludioxonil. XXtom1806 is the fludioxonil-resistant field isolate, and strains XXtom-Lab1, XXtom-Lab3, XXtom-Lab4, and XXtom-Lab5 are fludioxonilresistant laboratory strains. Data represent the arithmetic means for mycelial growth inhibition using at least eight replicates samples in each treatment. 
as well as in dimethachlon-resistant isolates of Sclerotinia sclerotiorum and fenhexamid-resistant isolates of $B$. cinerea (Zhou et al. 2014, 2017). Taken together, these results indicate that the influence of fungicides resistance on fitness parameters is primarily determined by particular resistance mechanisms and target genes rather than by the species of fungus (Qiu et al. 2018).

Although the mode of action of fludioxonil is still not characterized in detail, it seems that the target of fludioxonil is the HOG1

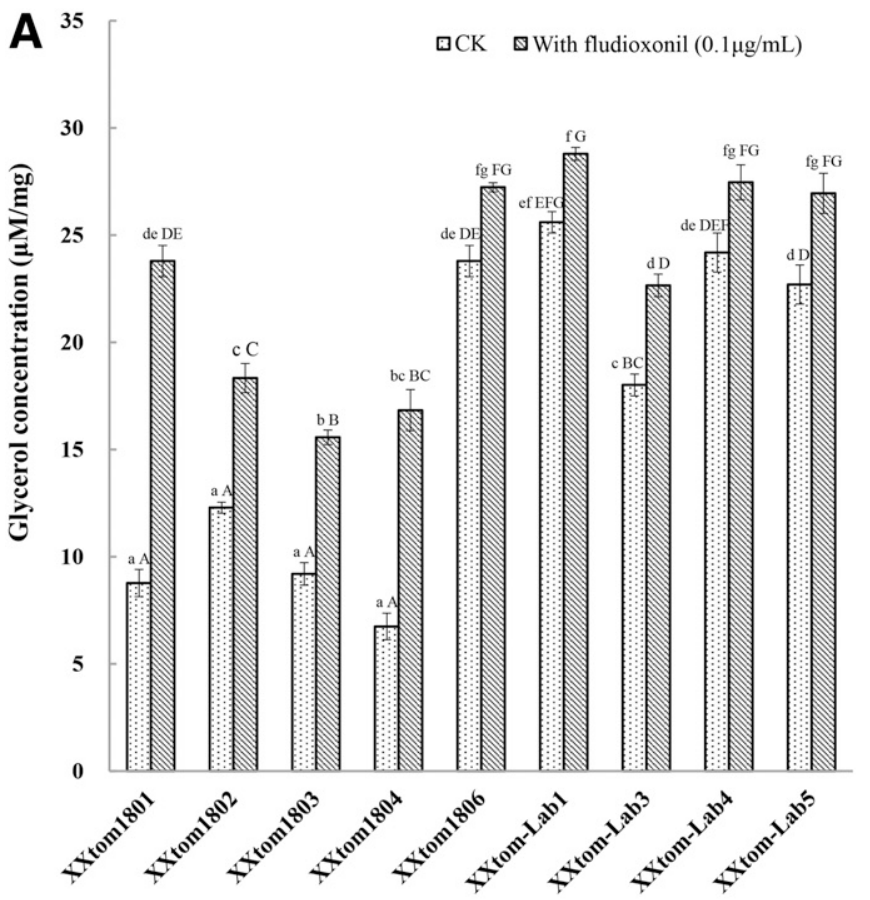

Isolates of Botrytis cinerea

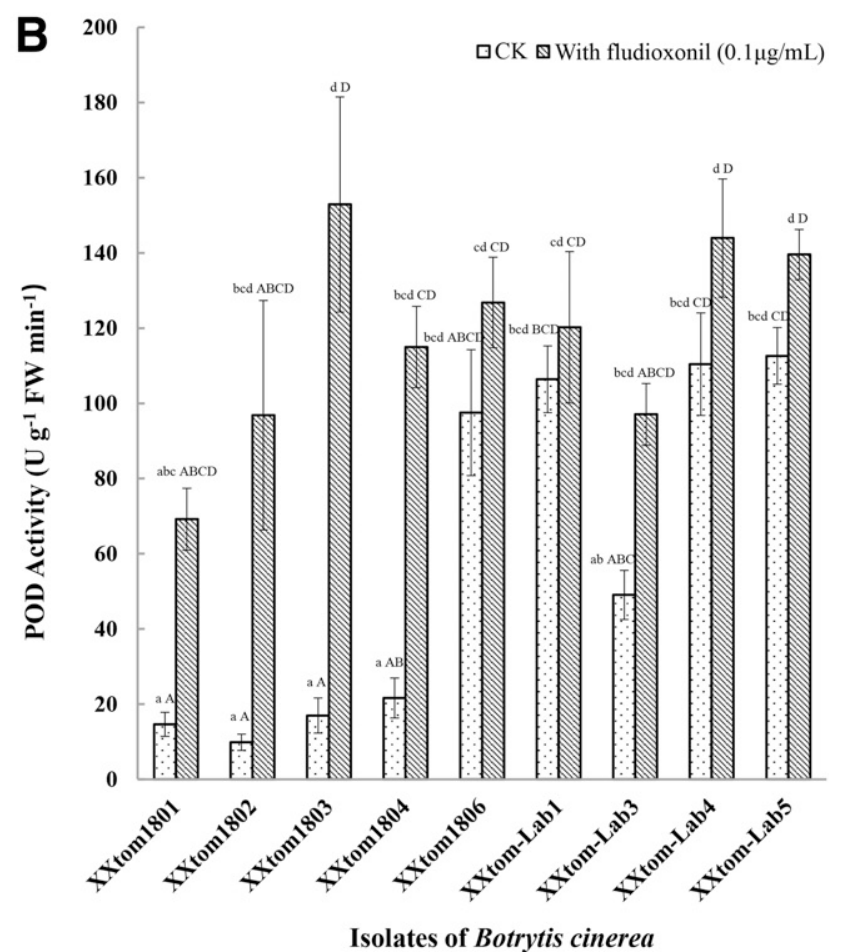

Fig. 2. A, Glycerol content and B, peroxidase (POD) activity of four sensitive and five fludioxonil-resistant strains of Botrytis cinerea. Error bars denote the standard errors from two separate experiments. Different letters above columns indicate significant differences according to Fisher's least significant difference test $(\alpha=0.05$ and $\alpha=0.01)$. FW: Fresh weight.

Table 3. Mutations in the BOs1 protein sequence of fludioxonil-resistant strains of Botrytis cinerea and Bipolaris maydis

\begin{tabular}{|c|c|c|c|c|c|}
\hline Species & Resource & Resistance type $^{y}$ & Mutations & Structural domain $^{z}$ & Reference \\
\hline B. cinerea & Laboratory & LR & No mutation & - & Ren et al. (2016) \\
\hline B. cinerea & Field & LR & $\begin{array}{l}\text { F127S, V287G, I365N, I365S, V1136I, } \\
\text { A1259T }\end{array}$ & $\begin{array}{l}\mathrm{N} \text { terminus, HAMP, Rec, and } \\
\mathrm{C} \text { terminus }\end{array}$ & Gong et al. (2018) \\
\hline B. cinerea & Field & MR & F127S, V287G, I365N, V1136I, A1259T & $\begin{array}{l}\mathrm{N} \text { terminus, HAMP, Rec, and } \\
\mathrm{C} \text { terminus }\end{array}$ & Gong et al. (2018) \\
\hline B. cinerea & Field & HR & I365S, V1136I, A1259T & HAMP, Rec, and C terminus & Gong et al. (2018) \\
\hline B. cinerea & Laboratory & HR & Q846stop, E253D, 838stop, G415D & HATPase_c, HAMP & Ren et al. (2016) \\
\hline B. cinerea & Field & HR & $\begin{array}{l}\text { R319K, V336M, D337 N, V346I, A350S, } \\
\text { Q369P, N373S, G262S, Q369P, N373S, } \\
\text { G311R, G265D, N609T, G545E }\end{array}$ & HAMP & Ren et al. (2016) \\
\hline B. cinerea & Field & HR & I365S, S531G, T565N, T1267A & HAMP, $\mathrm{C}$ terminus & This study \\
\hline B. cinerea & Laboratory & HR & $\begin{array}{l}\text { No mutation, G415D, P1051S, V1241M, } \\
\text { 240stop, Q846S, I1126S }\end{array}$ & HAMP, HATPsae_c, C terminus & This study \\
\hline B. cinerea & Field & HR & F127S, I365N, S426P, G538R, A1259T & $\mathrm{N}$ terminus, HAMP, $\mathrm{C}$ terminus & Sang et al. (2018) \\
\hline B. maydis & Laboratory & HR & Z1125K, 34-bp deletion fragment & Rec domain & Han et al. (2017) \\
\hline
\end{tabular}

y Resistance level indicating degree of sensitivity to fludioxonil. HR, high resistance; LR, low resistance; MR, medium resistance.

${ }^{z}$ Domain characteristics according to Ren et al. (2016). HAMP, histidine kinases, adenylyl cyclases, methyl-accepting chemotaxis receptors, and phosphatases.

Table 4. The 50\% effective concentration values of Botrytis cinerea isolates to fludioxonil and select fungicides

\begin{tabular}{|c|c|c|c|c|c|c|c|c|c|}
\hline \multirow[b]{2}{*}{ Fungicides } & \multicolumn{4}{|c|}{ Fludioxonil-sensitive isolates } & \multicolumn{5}{|c|}{ Fludioxonil-resistant strains } \\
\hline & XXtom1801 & XXtom 1802 & XXtom1803 & XXtom1804 & XXtom1806 & XXtom-Lab1 & XXtom-Lab3 & XXtom-Lab4 & XXtom-Lab5 \\
\hline Fludioxonil & 0.073 & 0.065 & 0.030 & 0.025 & 18.06 & $>100$ & 68.46 & $>100$ & $>100$ \\
\hline Procymidone & 0.352 & 0.463 & 0.422 & 0.769 & 36.876 & $>50$ & $>50$ & 78.65 & $>50$ \\
\hline Iprodione & 0.869 & 1.768 & 0.723 & 1.364 & 0.987 & 96.78 & 68.96 & $>50$ & $>50$ \\
\hline Boscalid & 0.098 & 0.135 & 0.075 & 0.011 & 0.163 & 0.215 & 0.07 & 0.31 & 0.263 \\
\hline Carbendazim & 0.73 & 0.54 & 0.63 & 0.35 & 0.62 & 0.46 & 0.33 & 0.71 & 0.29 \\
\hline Tebuconazole & 0.185 & 0.026 & 0.082 & 0.116 & 0.076 & 0.074 & 0.211 & 0.075 & 0.112 \\
\hline Fluazinam & 0.096 & 0.037 & 0.134 & 0.008 & 0.091 & 0.010 & 0.163 & 0.045 & 0.034 \\
\hline
\end{tabular}


cascade of the MAPK signaling pathway (Brandhorst and Klein 2019; Gong et al. 2018; Qiu et al. 2018; Ren et al. 2016). The results of this study confirmed that both the fludioxonil-resistant field isolate and the resistant laboratory strains exhibited hypersensitivity to the adverse osmotic conditions imposed by $\mathrm{NaCl}$ and glucose. The fitness of resistant isolates is an extremely important factor regarding the risk for the development of fungicide resistance (Brent and Hollomon 2007).

POD is one of the key protective enzymes associated with pathogenesis of fungi (Duan et al. 2014; Prestamo and Manzano 1993; Yao and Tian 2005). It is, therefore, interesting to note that POD activity is higher in the fludioxonil-resistant mutants compared with sensitive isolates in both $B$. cinerea and S. sclerotiorum (Duan et al. 2014; Gong et al. 2018; Li et al. 2017). This study confirmed these observations, finding that the resistant isolates had much higher POD activity than the sensitive ones and that fludioxonil at $0.1 \mu \mathrm{g} / \mathrm{ml}$ increased POD activity, particularly in the sensitive isolates. Taken together, these results provide further evidence of the link between fludioxonil resistance and POD activity and indicate that altered POD activity could be another contributing factor in the reduced fitness of fludioxonil-resistant $B$. cinerea isolates.

There is growing evidence that mutations in fungal MAPK proteins can contribute to fludioxonil resistance. For example, mutations in the N-terminal region of $O s 1$ have been related to fludioxonil resistance in several species of fungi (Avenot et al. 2005; Ren et al. 2016), whereas numerous studies have documented a range of mutations in the fludioxonil target protein BOs1 that can lead to the fludioxonil resistance (Table 3). This study also found that the fludioxonil-resistant field isolate (XXtom1806), which was collected from Xinxiang city of Henan Province, contained an amino acid change of I365S as well as three changes (S531G, T565N, and T1267A) that have not previously been documented in Henan Province (Ren et al. 2016). Furthermore, all of the four mutations were located in the functional domain of the HAMP motif in the fludioxonil-resistant field isolate, providing strong evidence that this isolate obtains resistance via impaired binding of fludioxonil to its target protein site, a mechanism that has been reported previously (Gong et al. 2018). However, the observation that the fludioxonilresistant laboratory strains contained other amino acid changes indicates alternative resistant mechanisms, which could also explain the different degrees of resistance observed among the different isolates. For example, the laboratory strain XXtom-lab5 contained no amino acid changes in its $B O s 1$ gene at all but exhibited high levels of resistance, indicating that other mechanisms, such as detoxification, are important aspects of fludioxonil resistance in $B$. cinerea and that further molecular and genetic analyses are needed to fully characterize the molecular mechanisms of fludioxonil resistance. In addition, the results of this study found strong evidence of positive crossresistance between fludioxonil and the dicarboximide fungicides procymidone and iprodione, which is not surprising given their similar mode of action. Meanwhile, no cross-resistance was found between fludioxonil and any of the other fungicides tested, including boscalid, carbendazim, tebuconazole, and fluazinam (Table 4). These results indicated that the inclusion of the latter fungicides within an integrated pest management program could help to minimize the risk of fludioxonil resistance developing.

\section{Literature Cited}

Amiri, A., Heath, S. M., and Peres, N. A. 2013. Phenotypic characterization of multi-fungicide resistance in Botrytis cinerea isolates from strawberry fields in Florida. Plant Dis. 97:393-401.

Amiri, A., and Peres, N. A. 2014. Diversity in the erg27 gene of Botrytis cinerea field isolates from strawberry defines different levels of resistance to the hydroxyanilide fenhexamid. Plant Dis. 98:1131-1137.

Amiri, A., Zuniga, A. I., and Mertely, J. 2014. First report on resistance to pyraclostrobin, thiophanate-methyl, fenhexamid and boscalid in Botrytis cinerea from eucalyptus seedlings in Florida greenhouses. Plant Dis. 98:851.

Avenot, H., Simoneau, P., Iacomi-Vasilescu, B., and Bataillé-Simoneau, N. 2005. Characterization of mutations in the two-component histidine kinase gene AbNIK1 from Alternaria brassicicola that confer high dicarboximide and phenylpyrrole resistance. Curr. Genet. 47:234-243.
Avenot, H. F., and Michailides, T. J. 2015. Detection of isolates of Alternaria alternata with multiple-resistance to fludioxonil, cyprodinil, boscalid and pyraclostrobin in California pistachio orchards. Crop Prot. 78:214-221.

Brandhorst, T. T., and Klein, B. S. 2019. Uncertainty surrounding the mechanism and safety of the post-harvest fungicide fludioxonil. Food Chem. Toxicol. 123: 561-565.

Brent, K., and Hollomon, D. 2007. Fungicide Resistance: The Assessment of Risk, Fungicide Resistance Action Committee, 2nd Revised Ed. AIMprint, Brussels, Belgium.

Dry, I. B., Yuan, K. H., and Hutton, D. G. 2004. Dicarboximide resistance in field isolates of Alternaria alternata is mediated by a mutation in a two-component histidine kinase gene. Fungal Genet. Biol. 41:102-108.

Duan, Y. B., Ge, C. Y., and Zhou, M. G. 2014. Molecular and biochemical characterization of Sclerotinia sclerotiorum laboratory mutants resistant to dicarboximide and phenylpyrrole fungicides. J. Pestic. Sci. 87:221-230.

Elad, Y., Williamson, B., Tudzynski, P., and Delen, N. 2007. Botrytis spp. and disease they cause in agricultural systems-an introduction. Pages 1-8 in: Botrytis: Biology, Pathology and Control. Y. Elad, B. Williamson, P. Tudzynski, and N. Delen, eds. Springer Netherlands, Berlin, Germany.

Gong, C. W., Qin, Y. M., Qu, J. S., and Wang, X. G. 2018. Resistance detection and mechanism of strawberry Botrytis cinerea to fludioxonil in Sichuan province. Sci. Agric. Sin. 51:4277-4287.

Han, X., Zhao, H., Ren, W. C., Lv, C. Y., and Chen, C. J. 2017. Resistance risk assessment for fludioxonil in Bipolaris maydis. Pestic. Biochem. Physiol. 139:32-39.

Hu, W. Q., Zhu, W. G., and Zhang, R. R. 2011. Screening and identification of multi-drug resistant Botrytis cinerea strains. Chin. J. Pestic. Sci. 13:586-590.

Jung, K., Fried, L., Behr, S., and Heermann, R. 2012. Histidine kinases and response regulators in networks. Curr. Opin. Microbiol. 15:118-124.

Leroux, P., Fritz, R., Debieu, D., Albertini, C., Lanen, C., Bach, J., Gredt, M., and Chapeland, F. 2002. Mechanisms of resistance to fungicides in field strains of Botrytis cinerea. Pest Manag. Sci. 58:876-888.

Lew, R. R. 2010. Turgor and net ion flux responses to activation of the osmotic MAP kinase cascade by fludioxonil in the filamentous fungus Neurospora crassa. Fungal Genet. Biol. 47:721-726.

Li, H. X., and Xiao, C. L. 2008. Characterization of fludioxonil-resistant and pyrimethanil-resistant phenotypes of Penicillium expansum from apple. Phytopathol. 98:427-435.

Li, J. L., Kang, T. H., Talab, K. M. A., Zhu, F. X., and Li, J. H. 2017. Molecular and biochemical characterization of dimethachlone resistant isolates of Sclerotinia sclerotiorum. Pestic. Biochem. Physiol. 138:15-21.

Liang, H. J., Di, Y. L., Li, J. L., and Zhu, F. X. 2015. Baseline sensitivity and control efficacy of fluazinam against Sclerotinia sclerotiorum. Eur. J. Plant Pathol. 142:691-699.

Liu, H. P., Han, J. C., and Yan, X. Y. 2003. Detction of resistance of Botrytis cinerea pers to carbendazim in Fulvia fulva. Chin. J. Shanxi Agric. Univ. 23:93-97.

Ma, H. X., Feng, X. J., and Chen, Y. 2009. Occurrence and characterization of dimethachlon insensitivity in Sclerotinia sclerotiorum in Jiangsu province of China. Plant Dis. 93:36-42.

Malandrakis, A. A., Vattis, K. N., Doukas, E. G., and Markoglou, A. N. 2013. Effect of phenylpyrrole-resistance on fitness parameters and ochratoxin production in Aspergillus carbonarius. Int. J. Food Microbiol. 165:287-294.

Milvia, D. M., Rotolo, C., Masiello, M. 2014. Occurrence of fungicide resistance in populations of Botryotinia fuckeliana (Botrytis cinerea) on table grape and strawberry in south Italy. Pest Manag. Sci 70:1785-1796.

Peters, R. D., Platt, H. W., Drake, K. A., Coffin, R. H., Moorehead, S., Clark, M. M., Al-Mughrabi, K. I., and Howard, R. J. 2008. First report of fludioxonil-resistant isolates of Fusarium spp. causing potato seed-piece decay. Plant Dis. 92:172.

Prestamo, G., and Manzano, P. 1993. Peroxidases of selected fruits and vegetables and the possible use of ascorbic acid as an antioxidant. Hortic. Sci. (Prague) 28: 48-80.

Qiu, J., and Shi, J. 2014. Genetic relationships, carbendazim sensitivity and mycotoxin production of the Fusarium graminearum populations from maize, wheat and rice in eastern China. Toxins (Basel) 6:2291-2309.

Qiu, J. B., Yu, M. Z., Yin, Q., Xu, J. H., and Shi, J. R. 2018. Molecular and characterization, fitness and mycotoxin production of Fusarium asiaticum strains resistant to fludioxonil. Plant Dis. 102:1759-1765.

Ren, W. C., Shao, W. Y., Han, X., Zhou, M. G., and Chen, C. J. 2016. Molecular and biochemical characterization of laboratory and field mutants of Botrytis cinerea resistant to fludioxonil. Plant Dis. 100:1414-1423.

Rosslenbroich, H. J., and Stuebler, D. 2000. Botrytis cinerea-history of chemical control and novel fungicides for its management. Crop Prot. 19:557-561.

Sang, C. W., Ren, W. C., Wang, J. J., Xu, H., Zhang, Z. H., Zhou, M. G., Chen, C. J., and Wang, K. 2018. Detection and fitness comparison of target-based highly fludioxonil-resistant isolates of Botrytis cinerea from strawberry and cucumber in China. Pestic. Biochem. Physiol. 147:110-118.

Staats, M., van Baarlen, P., and van Kan, J. A. L. 2005. Molecular phylogeny of the plant pathogenic genus Botrytis and the evolution of host specificity. Mol. Biol. Evol. 22:333-346.

Tückmantel, S., Greul, J. N., Janning, P., Brockmeyer, A., Grütter, C., Simard, J. R., Gutbrod, O., Beck, M. E., Tietjen, K., Rauh, D., and Schreier, P. H. 2011. Identification of Ustilago maydis Aurora kinase as a novel antifungal target. ACS Chem. Biol. 6:926-933. 
van Kan, J. A. L. 2006. Licensed to kill: The lifestyle of a necrotrophic plant pathogen. Trends Plant Sci. 11:247-253.

van Kan, J. A. L., Stassen, J. H. M., Mosbach, A., Van Der Lee, T. A. J., Faino, L. G., Farmer, A. D., Papasotiriou, D. G., Zhou, S. G., Seidl, M. F., Cottam, E., Edel, D. Q., Hahn, M., Schwartz, D. C., Dietrich, R. A., Widdison, S., and Scalliet, G. 2017. A gapless genome sequence of the fungus Botrytis cinerea. Mol. Plant Pathol. 18:75-89.

Williamson, B., Tudzynski, B., Tudzynski, P., and van Kan, J. A. L. 2007. Botrytis cinerea: The cause of grey mold disease. Mol. Plant Pathol. 8:561-580.

Wu, D. X., Zhang, R. S., Han, X., Wang, J. X., Zhou, M. G., and Chen, C. J. 2015. Resistance risk assessment for fludioxonil in Stemphylium solani. Ann. Appl. Biol. 167:277-284.

Yao, H. J., and Tian, S. P. 2005. Effects of pre- and post-harvest application of salicylic acid or Methyl jasmonate on inducing disease resistance of sweet cherry fruit in storage. Postharvest Biol. Technol. 35:253-262.
Yoshimi, A., Kojima, K., Takano, Y., and Tanaka, C. 2005. Group III histidine kinase is a positive regulator of Hog1-type mitogen-activated protein kinase in filamentous fungi. Eukaryot. Cell 4:1820-1828.

Zhang, R. J., Yan, X. Q., Han, J. C., and Liu, H. P. 2003. Detection of resistance to diethofencarb (NPC) in Botrytis cinerea Pers. Chin. J. Shanxi. Agri. Univ. 23:308-311.

Zhang, W., Qiao, G. H., and Hu, J. B. 2013. Evaluation on resistance of grape gray mold pathogen Botrytis cinerea to pyrimethanil in China. Sci. Agric. Sin. 46:1208-1212.

Zhang, X., and Ma, X. 2014. Advances of mutation sites associated with fungicide resistance in Botrytis cinerea and its molecular detection methods. Curr. Biotechnol. 4:251-257.

Zhou, F., Lu, F., Zhang, C., Qi, H. X., Wang, X. D., and Zhang, G. Z. 2017. Occurrence of fenhexamid resistance in Botrytis cinerea from greenhouse strawberries in China. J. Phytopathol. 165:455-462.

Zhou, F., Zhang, X. L., Li, J., and Zhu, F. X. 2014. Dimethachlon resistance in Sclerotinia sclerotiorum in China. Plant Dis. 98:1221-1226. 